\title{
端部に高力ボルト重ね継手を有する H 形鋼梁の塑性変形性状 INELASTIC BEHAVIOR OF H-SHAPED BEAMS WITH LAP JOINTS
}

\author{
千田 光*, 鈴木敏郎**, 小河利 行** \\ Hikaru SENDA, Toshiro SUZUKI and Toshiyuki OGAWA
}

\begin{abstract}
A series of loading tests on $\mathrm{H}$-shaped beams with lap joints is conducted in order to investigate the effect of these joints on inelastic behavior of the beams. Results indicate that deformation capacity of such beams is greater than prediction based on the assumption that the joint area is completely rigid. A non-linear analytical method for calculating the load-deformation relationship of the beams is developed based on the equilibrium and compatibility relationships between stub and strip elements divided at the location of bolts. The theory and test results are in good agreement and it is shown that the ratio of joint deformation to total deformation is considerably large when the beam is short.
\end{abstract}

keywords : T-stub, high-strength bolt, lap joint, inelastic behavior, non-linear analysis スプリットティー，高力ボルト，重水継手，塑性変形性状，非線形解析

\section{1. 序}

スプリットティー形式の柱梁接合部の特徴は, エンド プレート形式の柱梁接合部やブラケット形式の梁継手と 異なり，曲げモーメントの最大となる梁の端部が高力ボ ル卜摩擦接合部になっていることである。このため, 摩 擦接合部が梁の復元力特性に与える影響はかなり大きい と予想される。田中ら”はスプライス・プレート形式に よる高力ボルト接合継手を有する梁の復元力特性につい て総合的な実験を行っている。また，梁端部に 1 而せん 断の重ね継手を有する場合についての研究 2) 4)もいくつ かあるが，それらは滑り耐力および最大耐力と滑り変形 の検討に主眼が置かれ，滑りが生じて以降の塑性変形性 状についての榆討は不十分である。

通常，高力ボルト摩擦接合部は，その摩擦耐力がボル 卜孔矢損を考虑した目材の降伏酎力をやや上回るように 設計される。梁が全塑性モーメントに達して塑性変形を 始める時には，接合部にはすでに滑りが生じており，高 カボルトと板は支圧の状態になっていると考えられる。

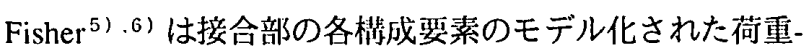

変形関係をもとに，高力ボル卜支圧接合部の弾塑性性状 と終局耐力を求める解析法を提案した。ただし，その解 析対象は引張力を受ける鋼板の 2 面せん断の乫合せ継手 であるので，これを曲げを受けるH形鋼梁の接合部全体 に対してそのまま適用することはできない。1 面せん断 の場合および圧縮力を受ける場合の継手の挙動, 梁とし て見た場合のウェブの応力伝達，さらにモーメント勾配 の影響を考虑する必要がある。

本研究は，端部にスプリットティー接合に代表される 高力ボル卜重ね継手を有する $\mathrm{H}$ 形鋼梁の塑性変形性状を 梁の長さ，ボルト本数等を変数とした実験によって明ら かにするとともに，接合部の荷重-変形関係を予測する非 線形解析法を提案することを目的とするものである。

\section{2. 実駼概要}

\section{1 試験体}

表ー1に試䀦体の一覧を, 図ー1に試験体の詳細を示 す。また，鋼材の機械的性質を表一 2 に示す。試験体は 細幅 $\mathrm{H}$ 形鋼を想定して高力ボルトを 2 列配置とした S シ
“住友金属工業

**. 東京工業大学 教授・工博
Sumitomo Metal Industries Co., Ltd.

Prof., Tokyo Institute of Technology, Dr. Eng. 
リーズと中幅を想定して千鳥配置としたMシリーズに分 かれる。Sシリーズでは梁の長さおよびボルト径を，M シリーズではボルト本数を実験変数とした。また，両シ リーズについて，比較のために溶接接合形式の試験体を 1 体ずつ用意した。さらに，繰り返し载荷の影響を見る ために，S170-10 と全く同じ試験体をS170-10C として用 意した。ボルトの孔径は，M16でボルト径 $+1 \mathrm{~mm}, \mathrm{M} 20$ でボルト径+ $1.5 \mathrm{~mm}$ とした。スプリットティーと梁フラ ンジの摩擦面は黒皮をサンダーで除去して赤さびを発生 させた。高力ボルトの締め付けは, 標準ボル卜張力 (M16 は11.7tf, M20は18.2tf)を目標としてトルクコントロール 法により締め付けた。

\section{2 载荷・測定方法}

図ー2に示すように，試験体のスプリットティーを载 荷ビームのエンドプレートに高力ボルトで接合し，両端 をピンローラーで支持した単純梁形式で載荷を行った。 繰り返し載荷の試験体の載荷パターンは, 部材角で正負

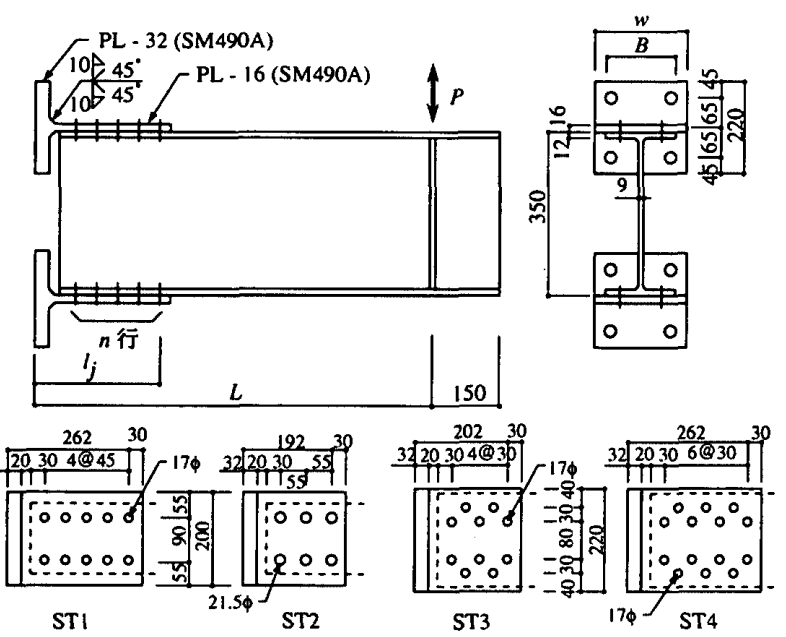

(a) スプリットティー接合タイフ

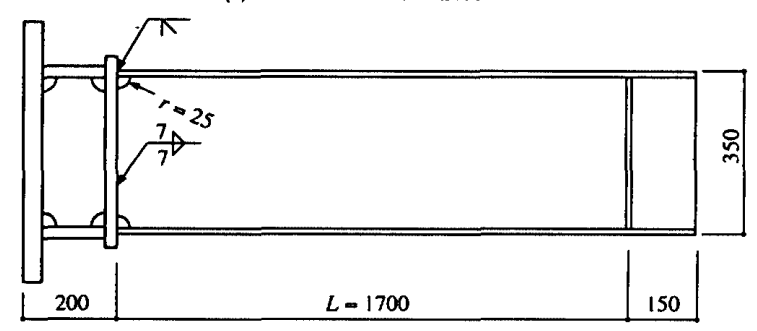

(b) 溶接タイブ (S170W, MI70W)

图-1 試験体の形状・寸法

とも0.01 radから0.04radまで0.01 radピッチで 1 回ずつ繰り 返し，その後最大荷重まで載荷した。

変位の湘定は載荷ビームの端部と試験体の支持部の鉛 直変位および上下のスプリットティーのフランジ中央間 の回転変位について行った。これらの鉛直変位と回転変 位から図ー3で定義される部材角を計算する。なお，回 転量測定冶具はスプリットティーの両切断面のフランジ 心とウェブの交点に取り付けてあるので, 部材角には 引張ボルトとティーフランジの変形の影響は含まれな い。また, 梁のフランジ先端の小口面とウェブ面のひず みをW.S.G.で測定した。

\section{3 実験結果}

\section{（1）単調載荷の試験体の耐力と変形能力}

単調載荷の各試験体の端部（スプリットティー接合の 場合はティーフランジ面，溶接接合の場合は溶接位置） の曲げモーメント $M$ とその位置から測った部材角 $\theta$ と の関係を図ー4に示す。また, 曲げモーメントの最大値 $M_{\text {max }}$ とそのときの部材角 $\theta_{\text {max }}$ を表一 3 に示す。最大耐 力はS170-6を除いて梁の圧縮フランジの局部座屈によっ て決定した。S170-6については梁の引張フランジ側の最

表一1 試験体の一覽

\begin{tabular}{|c|c|c|c|c|c|}
\hline 名称 & 粱サイズ & $L(\mathrm{~mm})$ & 高力ボルト & 載荷 & S.T. No. \\
\hline S170W & \multirow{7}{*}{$\begin{array}{c}\text { BH- } 350 \times 150 \\
\times 9 \times 12\end{array}$} & 1700 & （溶接） & 単調 & \\
\hline$\$ 100-10$ & & 1000 & $10-\mathrm{M} 16$ & 単調 & STI \\
\hline$S 130-10$ & & 1300 & 10-M16 & 単調 & STI \\
\hline S170-10 & & 1700 & $10-\mathrm{M} 16$ & 単調 & STI \\
\hline S250-10 & & 2500 & $10-\mathrm{M} 16$ & 単調 & ST1 \\
\hline S170-6 & & 1700 & 6-M20 & 単調 & ST2 \\
\hline S170-10C & & 1700 & $10-\mathrm{M} 16$ & 綠り返し & STI \\
\hline MI70W & \multirow{3}{*}{$\begin{array}{c}\text { BH- } 350 \times 200 \\
\times 9 \times 12 \\
(\mathrm{SS} 400)\end{array}$} & 1700 & （溶接） & 単調 & \\
\hline M170-10 & & 1700 & 10-M16，千鳥 & 単調 & ST3 \\
\hline M170-14 & & 1700 & 14-M16，千鳥 & 単調 & ST 4 \\
\hline 名称の意味 & \multicolumn{5}{|c|}{$\begin{array}{l}\mathrm{S}: \text { 梁フランジ幅 } 150, \mathrm{M}: \text { 梁フランジ幅 } 200 \\
100 \sim 250: \text { 梁の長さ }(\mathrm{cm}) / .6 \sim-14: \text { 高力ボルト本数 } \\
\mathrm{W}: \text { 溶接タイブ/C : 繰り返し载荷 }\end{array}$} \\
\hline
\end{tabular}

表-2 材料の機械的性質

\begin{tabular}{|c|c|c|c|c|c|c|}
\hline 材料 & 鏩種 & $\begin{array}{c}\sigma_{y} \\
\left(\mathbf{f f} / \mathrm{cm}^{2}\right)\end{array}$ & $\begin{array}{c}\sigma_{u} \\
\left(\mathbf{f} / \mathrm{cm}^{2}\right)\end{array}$ & $\begin{array}{c}E_{s t} \\
\left(\mathbf{( f} / \mathrm{cm}^{2}\right)\end{array}$ & $\begin{array}{c}\varepsilon_{s t} \\
(\mu)\end{array}$ & $\begin{array}{c}\text { 伸ひ } \\
(\%)\end{array}$ \\
\hline PL-9 & SS400 & 3.10 & 4.66 & 33.0 & 22700 & 30.0 \\
\hline PL-12 & SS400 & 2.73 & 4.63 & 42.2 & 17400 & 29.2 \\
\hline PL-16 & SM490A & 3.74 & 5.13 & 34.9 & 20700 & 27.8 \\
\hline HTB M16 & F10T & 9.34 & 10.12 & & & 17.8 \\
\hline HTB M20 & F10T & 9.45 & 10.04 & & & 16.8 \\
\hline
\end{tabular}

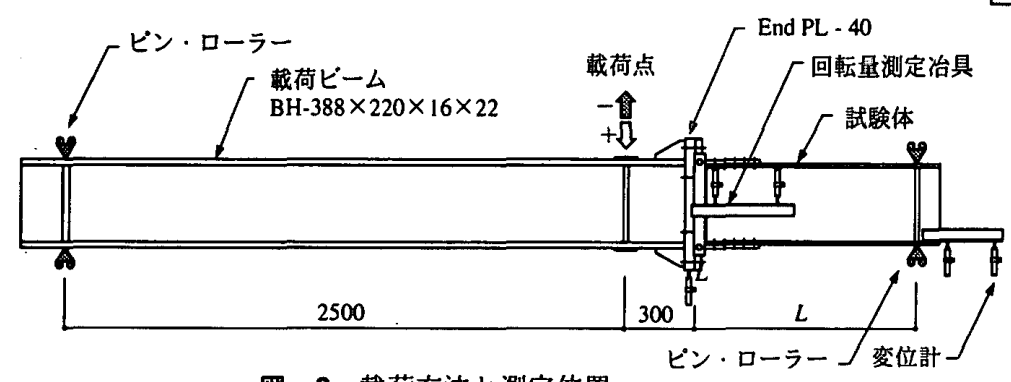

图-2 載荷方法と測定位置

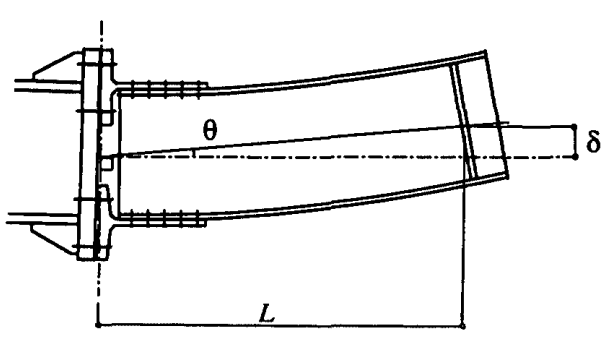

图一3 部材角の定義 
内端のボルト破断によって終了した。この原因は，この 位置で梁の引張フランジが大きな曲率で面外に曲げら れ，ボルトに強制引張力とせん断力が同時に作用したた めと考えられる。

同じ梁長さで比べると，スプリットティー形式の方が 溶接形式と比べて全般的に高い耐力を示している。ま た，梁の長さに対するスプリットティーの長さの比が大 きくなるほど耐力が上昇している。そこで，図ー6に示 すようにスプリットティーの部分が剛域であると仮定し て，最内端のボルト位置の曲げモーメントが全塑性モ一 メントに達するときの全体の曲げモーメント $M_{p j}$ とそれ に対応する弾性部材角 $\theta_{p j}$ で実験結果を無次元化すると

表一3 曲げモーメントと部材角の関係

\begin{tabular}{|c|c|c|c|c|c|c|c|c|}
\hline 試験体名 & $\begin{array}{c}M_{\text {max }} \\
(\text { if } \cdot \mathrm{m})\end{array}$ & $\begin{array}{c}\theta_{\max } \\
(1 / 100 \mathrm{rad})\end{array}$ & $\begin{array}{c}M_{p j} \\
(\text { (ff } \cdot \mathrm{m})\end{array}$ & $\begin{array}{c}\theta_{p j} \\
(1 / 100 \mathrm{rad})\end{array}$ & $\begin{array}{c}M_{m a r .} \\
I_{p j}\end{array}$ & $\begin{array}{l}\theta_{\max } \\
\theta_{p j}\end{array}$ & $\left|\begin{array}{c}E_{\max } \\
(1001 f \cdot \mathrm{m})\end{array}\right|$ & $\eta^{*}$ \\
\hline S170W & 35.3 & 7.62 & 24.5 & 0.512 & 1.443 & 14.9 & 234 & 18.7 \\
\hline$\$ 100-10$ & 47.1 & 8.26 & 33.1 & 0.164 & 1.423 & 50.4 & 340 & 62.6 \\
\hline $5130-10$ & 45.1 & 9.23 & 30.6 & 0.249 & 1.475 & 37.1 & 366 & 47.9 \\
\hline$\$ 170-10$ & 10.4 & 7.86 & 28.9 & 0.366 & .1 .400 & 21.5 & 280 & 26.4 \\
\hline$\$ 250-10$ & 38.0 & 10.11 & 27.3 & 0.605 & 1.392 & 16.7 & 331 & 20.0 \\
\hline$\$ 170-6$ & 38.0 & 9.92 & 27.6 & 0.404 & 1.377 & 24.6 & 316 & 28.3 \\
\hline S170-10C & 41.9 & 5.16 & 28.9 & 0.366 & 1.450 & 14.1 & & \\
\hline M170W & 39.5 & 5.90 & 30.1 & 0.498 & 1.310 & 11.9 & 209 & 13.9 \\
\hline M170-10 & 42.9 & 6.96 & 34.2 & 0.387 & 1.254 & 18.0 & 228 & 17.2 \\
\hline M170-14 & 46.2 & 5.99 & 35.6 & 0.356 & 1.299 & $16: 8$ & 246 & 19.3 \\
\hline
\end{tabular}

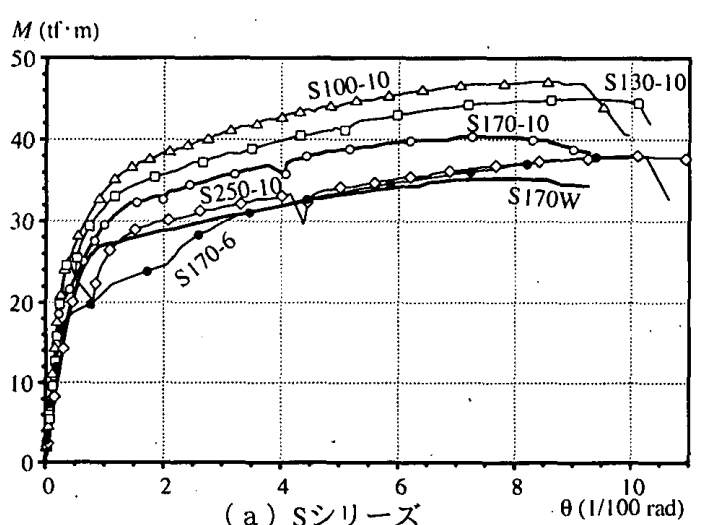

图 -4 曲げモーメントと部材角の関保

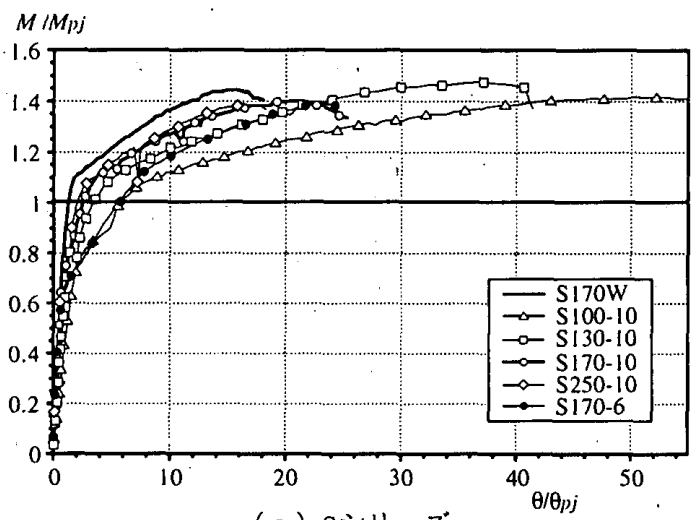

(a) Sシリーズ

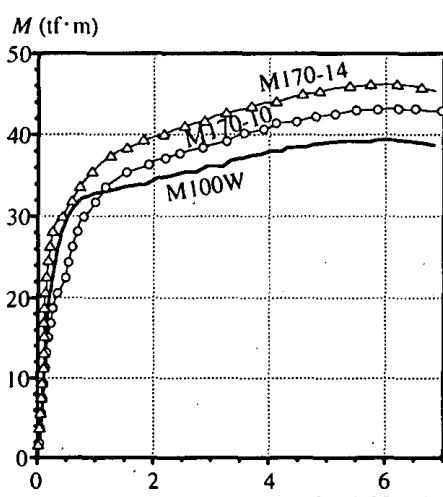

(b) Mシリーズ $\theta(1 / 100 \mathrm{rad})$

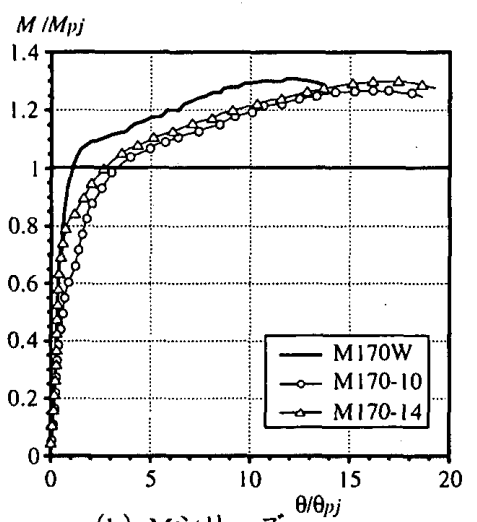

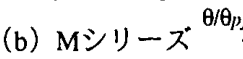

图-5 無次元化曲げモーメントと無次元化部材角の関係
図ー5および表ー3のようになる。ただし， $M_{p j}$ に対する せん断力の影響は考慮していない。

これによれば, 梁のサイズが同じならば，上記の方法 で無次元化したスプリットティー形式の梁の全塑性耐力 と最大耐力は, 溶接形式の梁とほほ同じになることがわ かる。このことは，ボルトが千鳥配置の場合についても いえることである。したがって，スプリットティー形式 の梁の耐力に関してはスプリットティー部分を剛域と考 えてよいと言える。

一方, 変形能力について見ると, スプリットティー形 式の梁の方が溶接形式と比べて無次元化最大部材角が大 きくなっている。また, 溶接形式の梁の曲げ風性がほほ $M_{p j}$ に至るまで一定であるのに対し，スプリットティー 形式の梁の場合は $M_{p j}$ の0.6 0.8 倍の付近から曲け風性 が低下し始めている。これは, 塑性ヒンジを仮定した位 置におけるフランジのボルト孔欠損の影響と考えられ る。しかし，剛性の低下の度合いは $M_{p j}$ 以降と比べると わずかであり，部材全体のエネルギ一吸収能力に与える 影響は小さいため，この位置での全塑性モーメントは全 断面有効と評価してよいと思われる。ただし，骬組み全 体として見ると，剛性の低下による他部材への応力の再 配分について考慮する必要があ万う。

摩擦面の滑りによる変形はあまり明確ではないが，上 下のフランジがそれぞれ平均してボルト孔のクリアラン スの半分だけ滑るとすると, ボ ルト径がM16のとき0.29/100 rad となり, 全体の変形の高々 $5 \%$ 程度である。

荷重一変形曲線形状が異なる ことを考虑して塑性変形能力を

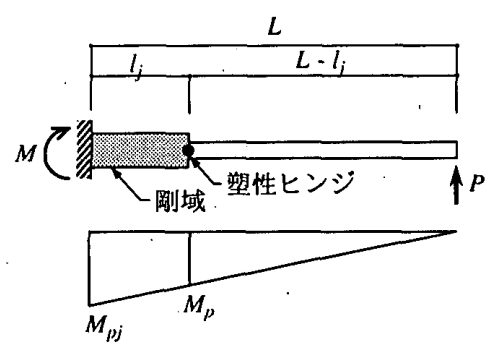

図-6 耐力評価モデル

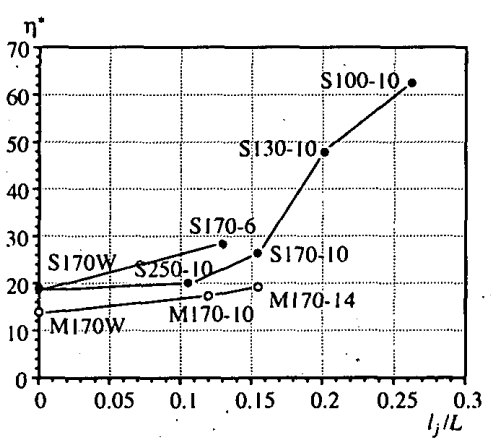

図-7 等価塑性変形倍率 


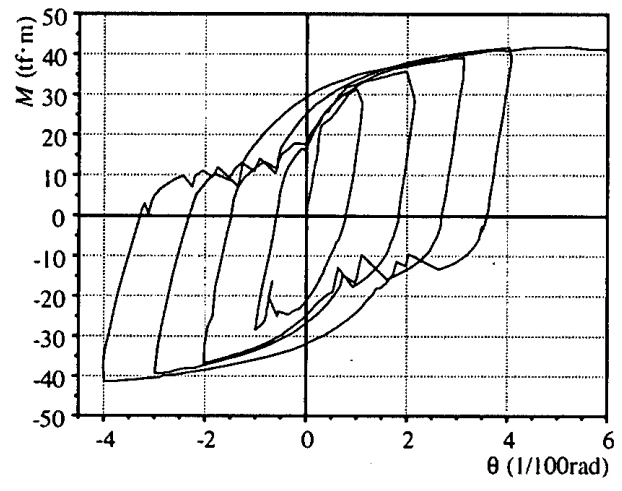

图-8 荷重一変形関係 (S170-10C)

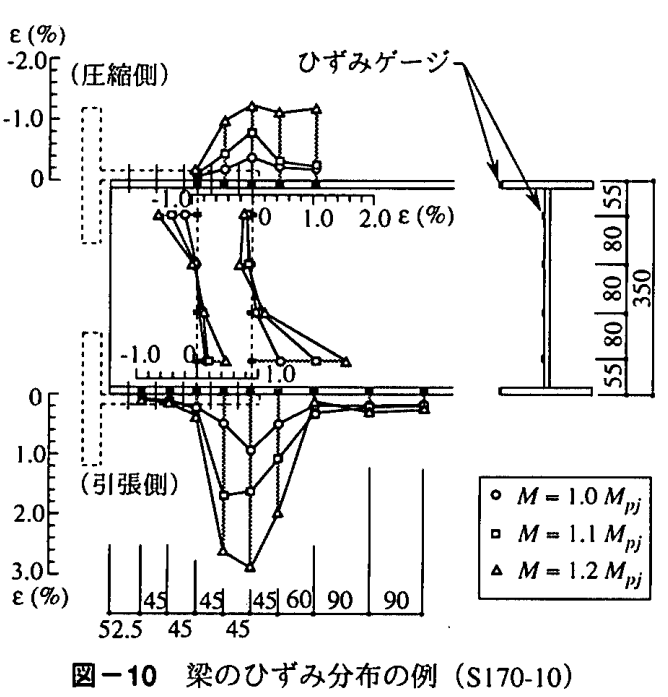

評価するために，各試験体が最大耐力に達するまで吸収 したエネルギー $E_{\text {max }}$ と，これを $M_{p j}$ と $\theta_{p j}$ の積で除した 等価塑性変形倍率 $\eta^{*}$ を表一3に示す。同じ長さの梁の場 合で比較すると，スプリットティー形式の方が溶接形式 と比べて $E_{\text {max }}$ が大きいことがわかる。また, 図一7に示 すようにスプリットティーの長さの梁の長さに対する比 $l_{j} / L$ が大きくなるほど $\eta^{*}$ も大きくなる傾向にある。溶 接形式の場合の塑性変形倍率が梁の長さによって変わら ないとすれば,このことは，スプリットティー形式の梁 の塑性変形能力はスプリットティー部を剛域と仮定して

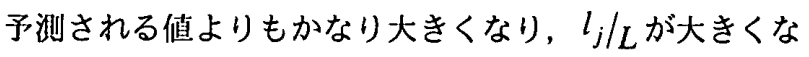
るほどそれが顕著になることを示している。

（2）繰り返し載荷の影響

図ー8に試験体 S170-10C の曲げモーメントと部材角の 関係を示す。最初の正側のサイクルでは摩擦面の滑りに よる変形は 0.2 / 100 rad 程度であり, 滑り音もなかった が，それ以降の負側のサイクルからは明確な滑り音を発 して滑り変形が増加し, 最終的には1.5/100 rad 程度の 滑り変形を生じた。また, 滑り耐力は田中らの実験 ${ }^{1)}$ と 同様に数サイクルで初期滑りの半分程度に低下し, 以後 は安定する。

正側と負側の各サイクルについて新たな荷重域に対応 する骨格部を変形の進展にしたがって順次つなぎ合わせ
ると，図ー9に示す骨格曲線が

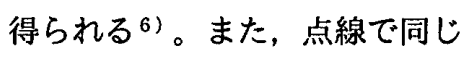
形状の試験体 (S170-10) の単 調載荷の結果を示す。これか $ら$, 繰り返し載荷時の荷重一変 形関係の骨格曲線は単調載荷時 の荷重一変形関係とほほ等価で あるといえる。一方, バウシン ガー部については, 滑り荷重と 滑り量の履歴則を評価すること が重要となるが, 検討は今後の 課題とする。

（3）ひずみ分布

図-10 に代表的な試験体 S170-10の梁のひずみ分布の 例を示す。フランジのひずみゲージは高力ボルトとの干 涉を避けるため, 接合部から外れた位置も含めて全て端 部の小口に貼ってある。また，材軸方向のひずみ分布を 見るために局部座屈の影響のない引張フランジ側の測定 点を多めにしている。ボルトおよびボルト孔が存在する ためフランジのひずみは断面の各部で一様ではないが, 材軸方向の分布としては最内端ボルト位置の内側にひず みが集中していることがわかる。これは，ボルト穴欠損 部の塑性化が進行した後, ひずみ硬化により周辺部へも 塑性化が進展するためであろう。また，引張側のひずみ が圧縮側の 2 倍程度になっている。これに対応して， ウエブのひずみも引張側の方が大きくなっており, 中立 軸が圧縮側に寄っている。

\section{3. 解析}

\section{1 解析方針}

スプリットティー接合された梁が逆対称の曲げモーメ ントを受けるときの曲げモーメントと梁の変形角の関係 を，モデル化された要素の荷重-変形関係をもとに解析す る。スプリットティーと梁の接合部を図ー11のようにモ デル化する。ティーウェブと梁を各ボルト位置で材軸と 直角に切断し，それぞれの要素間の力の釣り合いと変形 の適合を検討する。さらに, 梁全体としての変形を求め るために，梁の母材部を適当な長さで要素に分割してそ れぞれの要素の曲率と中立軸位置を求める。ただし，梁 の内端ボルト近傍の 1 個の要素については要素の長さを フランジ幅の $1 / 4$ とし, 要素片端のボルト孔欠損の影響 を考慮する。ここで，解析に際し以下の仮定を設ける。

(1) 梁の断面は平面を保持する。

(2) 梁のせん断変形は考慮しない。

(3) 梁とティーウェブとのすべりは考慮しない。

\section{2 解析方法}

引張側および圧縮側の $\mathrm{i}$ 番目のボルト 2 本が負担する せん断力をそれぞれ， $R_{t i}, R_{c i}$ とすると, ボルトのせん 


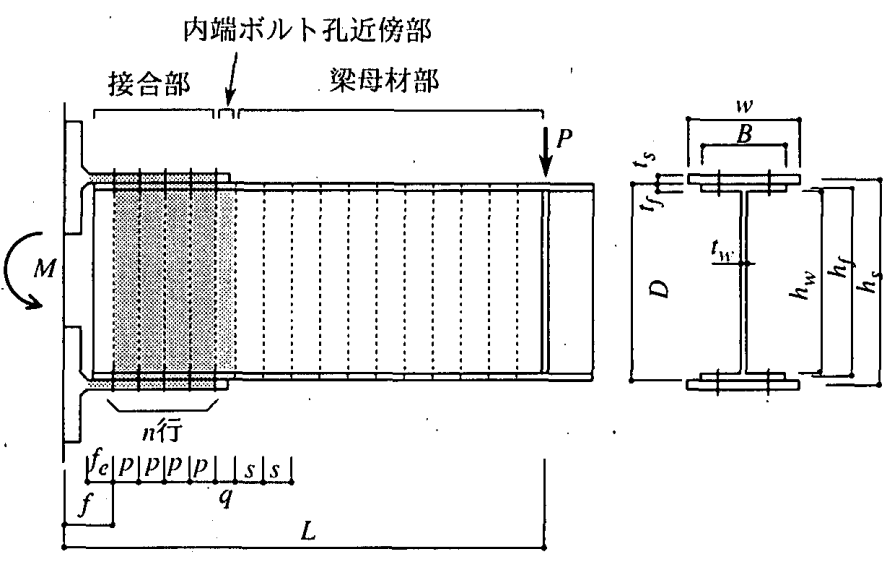

(a) 全体モデル

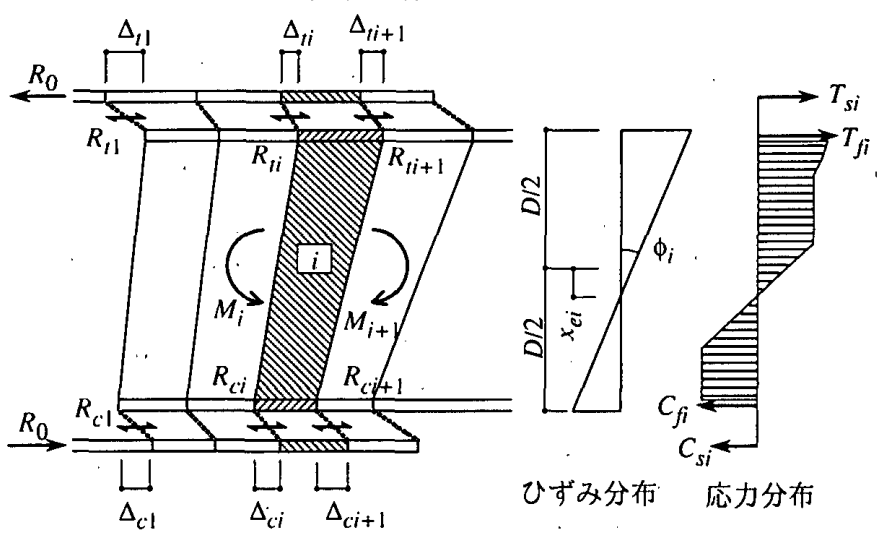

(b) 接合部モデル

图-11 解析モデル

断力の釣り合い条件より，次式が成り立つ。

$$
\begin{aligned}
& \sum_{i=1}^{n} R_{t i}=R_{0} \\
& \sum_{i=1}^{n} R_{c i}=R_{0}
\end{aligned}
$$

ここで， $R_{0}$ は次式で計算されるスプリットティーの根元 に作用する引張または圧縮力の絶対值である。

$$
R_{0}=\frac{(L-f) M}{L h_{s}}
$$

ただし， $M$ はティーフランジ面における梁の曲げモーメ ント, $L$ はティーフランジ面からの片持ち梁としての長 さ， $f$ はティーフランジ面から第 1 ボルトまでの距離, $h_{s}$ は上下のティーウェブの中心間の距離である。

次に，i番目のティーウェブと梁要素に作用する断面力 を考える。引張側のティーウェブの引張力 $T_{s i}$ および圧 縮側のティーウェブの引張力 $C_{s i}$ は次式で与えられる。

$$
\begin{aligned}
& T_{s i}=R_{0}-\sum_{j=1}^{i} R_{t j} \\
& C_{s i}=R_{0}-\sum_{j=1}^{i} R_{c j}
\end{aligned}
$$

$\mathrm{i}$ 要素の梁の平均曲率を $\phi_{i}$, 中立軸の断面中央からの距 䧹を $x_{c i}$ とすると，梁の引張フランジの引張力 $T_{f i}$ および 圧縮フランジの压縮力 $C_{f i}$ は次式で与えられる。

$$
T_{f i}=A_{f e} \Psi_{c l}\left[\phi_{i}\left(h_{f} / 2+x_{e i}\right)\right]
$$

$$
C_{f i}=A_{f e} \Psi_{e c}\left[\phi_{i}\left(h_{f} / 2-x_{e i}\right)\right]
$$

また，梁ウェブの中立軸より引張側の引張力 $T_{w i}$ お よび王縮側の圧縮力 $C_{w i}$ は次式で与えられる。

$$
\begin{aligned}
& T_{w i}=\int_{0}^{h_{w} / 2+x_{e i}} \Psi_{t}\left(\phi_{i} x\right) t_{w} d x \\
& C_{w i}=\int_{0}^{h_{w} / 2-x_{e i}} \Psi_{c}\left(\phi_{i} x\right) t_{w} d x
\end{aligned}
$$

ここで, $A_{f e}$ は梁フランジのボルト孔を控除した断 面積, $h_{f}$ は梁フランジの中心間の距離, $h_{w}$ は梁 ウェブの高さ， $t_{w}$ は梁ウェブの厚さである。 $\sigma_{e}=\Psi_{e t}(\bar{\varepsilon})$ および $\sigma_{e}=\Psi_{e c}(\bar{\varepsilon})$ はそれぞれ引張側と 圧縮側の梁フランジ要素の平均ひずみ $\bar{\varepsilon}$ とボルト孔 欠損断面についての有効応力 $\sigma_{e}$ の関係を近似する 関数，また， $\sigma=\Psi_{t}(\varepsilon)$ および $\sigma=\Psi_{c}(\varepsilon)$ はそれぞ れ梁ウェブの引張および圧縮についてのひずみと応 力の関係を近似する関数であり，詳細は次節で述べ る。

梁全体の軸力は 0 なので, 力の釣り合いより次式 が成り立つ。

$$
T_{s i}+T_{f i}+T_{w i}=C_{s i}+C_{f i}+C_{w i}
$$

一方，中立軸回りの曲げモーメントの釣り合い条 件より次式が成り立つ。

$$
\begin{aligned}
& T_{s i}\left(h_{s} / 2+x_{e i}\right)+C_{s i}\left(h_{s} / 2-x_{e i}\right) \\
& +T_{f i}\left(h_{f} / 2+x_{e i}\right)+C_{f i}\left(h_{f} / 2-x_{e i}\right)+M_{w i}=M_{i} \cdots
\end{aligned}
$$

ここで, $M_{w i}$ は梁ウェブの曲げモーメントで, 次式で計 算される。

$$
\begin{aligned}
M_{w i}= & \int_{0}^{h_{w} / 2+x_{e i}} \Psi_{t}\left(\phi_{i} x\right) x t_{w} d x \\
& +\int_{0}^{h_{w} / 2-x_{c i}} \Psi_{c}\left(\phi_{i} x\right) x t_{w} d x
\end{aligned}
$$

また， $M_{i}$ は次式で与えられる。

$$
M_{i}=M\{L-f-(i-1) p\} / L
$$

次に, i 要素の変形の適合を考える。梁フランジの圧 縮側の伸び $e_{i i}$ と引張側の縮み $e_{c i}$ は次式で与えられる。

$$
\begin{aligned}
& e_{i i}=p \phi_{i}\left(h_{f} / 2+x_{e i}\right) \\
& e_{c i}=p \phi_{i}\left(h_{f} / 2-x_{i i}\right)
\end{aligned}
$$

また，ティーウェブの引張側の縮み $e_{t i}^{\prime}$ と圧縮側の伸び $e_{c i}^{\prime}$ は次式で表すことができる。

$$
\begin{aligned}
& e_{t i}^{\prime}=p \Psi_{e t}^{\prime-1}\left(T_{s i} / A_{s e}\right) \\
& e_{c i}^{\prime}=p \Psi_{e c}^{\prime-1}\left(C_{s i} / A_{s e}\right)
\end{aligned}
$$

ここで, $p$ はボルトピッチ, $A_{s e}$ はティーウエブのボル 卜孔を控除した断面積である。また， $\bar{\varepsilon}=\Psi_{c t}^{\prime}-1\left(\sigma_{e}\right)$ およ び $\bar{\varepsilon}=\Psi_{c c}^{\prime-1}\left(\sigma_{e}\right)$ はそれぞれ引張側と圧縮側のティーウエ ブ要素の有効応力と平均ひずみの関係を近似する関数で 


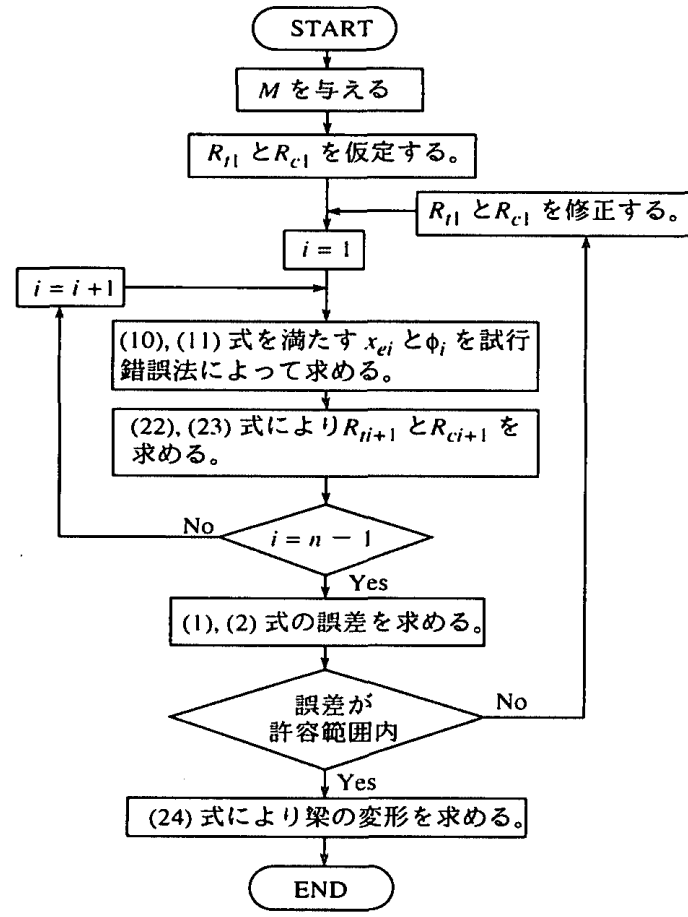

图-12 接合部の解析の流れ図

ある。さらに引引張および圧縮フランジの高力ボルトの 支圧変形量 $\Delta_{t i}$ と $\Delta_{c i}$ をせん断力の関数として次式で表 す。

$$
\begin{aligned}
& \Delta_{t i}=\Omega\left(R_{t i}\right) \\
& \Delta_{c i}=\Omega\left(R_{c i}\right)
\end{aligned}
$$

引張側および圧縮側それぞれについて，梁フランジと ティーウェブの変形の適合条件から次式が導かれる。

$$
\begin{aligned}
& e_{t i}+\Delta_{t i}=e_{t i}^{\prime}+\Delta_{t i+1} \\
& -e_{c i}+\Delta_{c i+1}=-e_{c i}^{\prime}+\Delta_{c i}
\end{aligned}
$$

この式は(18)，(19)式を使って次式のように書き換える ことができる。

$$
\begin{aligned}
& R_{t i+1}=\Omega^{-1}\left(e_{t i}-e_{t i}^{\prime}+\Delta_{t i}\right) \\
& R_{c i+1}=\Omega^{-1}\left(e_{c i}-e_{c i}^{\prime}+\Delta_{c i}\right)
\end{aligned}
$$

ここで， $\Omega^{-1}$ は $\Omega$ の逆関数である。これは， $\mathrm{i}$ 要素の変 形が分かれば (i+1) 番目の高力ボルトのせん断力が求まる
ことを示している。

(10)，(11)式の釣り合い条件式および(20)，(21)式の適 合条件式は，それぞれ $(n-1)$ 個の要素について成り立 つ。さらに，(1)，(2)式の釣り合い条件式を加えると， $(4 n-2)$ 個の連立方程式が得られる。一方，未知数は $R_{t i}, R_{c i}$ がそれぞれ $n$ 個， $\phi_{i}, x_{e i}$ がそれぞれ $(n-1)$ 個 であるので，これらについて解くことができる。

各要素の変形特性が非線形なため, 与えられた曲げ モーメントに対する接合部の変形を求めるためには，図 -12 に示す流れ図に従って反復計算を行う。解が得られ たら，接合部の変形による梁の部材角は次式で計算され る。

$$
\begin{aligned}
\theta= & \frac{f_{e} \Psi_{e l}^{\prime}-1\left(R_{0} / A_{s e}\right)+f_{e} \Psi_{e c}^{\prime-1}\left(R_{0} / A_{s c}\right)}{h_{s}} \frac{(L-f)}{L} \\
& +\frac{\Delta_{t 1}+\Delta_{c 1}}{D} \frac{(L-f)}{L}+\frac{\sum_{i=1}^{n-1} \phi_{i} p(L-f-i p)}{L} .
\end{aligned}
$$

梁の接合部以外の要素についても同様の解析を行う。

\section{3 要素の変形特性}

解析モデルを構成する各要素の変形特性を以下のよう にモデル化する。

\section{(1) 板要素の応力-ひずみ関係}

孔の明いていない鋼板の引張応力と引張ひずみの関係 については種々の数式モデルが提案されているが8).9)， 数学的取り扱いの便利さからから以下に示す指数関数モ デルを採用する。

$$
\left.\begin{array}{l}
\sigma=\Psi_{t}(\varepsilon) \\
0 \leq \varepsilon<\varepsilon_{y}: \Psi_{t}(\varepsilon)=E \varepsilon \\
\varepsilon_{y} \leq \varepsilon<\varepsilon_{s t}: \Psi_{t}(\varepsilon)=\sigma_{y} \\
\varepsilon_{s t} \leq \varepsilon: \Psi_{t}(\varepsilon)=\sigma_{y} c_{0}\left(\varepsilon / \varepsilon_{y}\right)^{n}
\end{array}\right\}
$$

ここで, $\varepsilon_{y}=\sigma_{y} / E, \varepsilon_{s t}=\left(1 / c_{0}\right)^{1 / n} \varepsilon_{y}, \sigma_{y}$ は降伏応力, $E$ はヤング率, $c_{0}$ と $n$ はひずみ硬化領域の曲線形状を決 める材料定数である。本実験の素材試験によれば，図一 13 に示すようにPL-9(SS400), PL-12(SS400)ともに $c_{0}=0.54, n=0.24$ が適当である。

圧縮応力と圧縮ひずみの関係も(25)式と同様に表すこ とができる。ただし，鋼素材の応力とひずみを真応力と

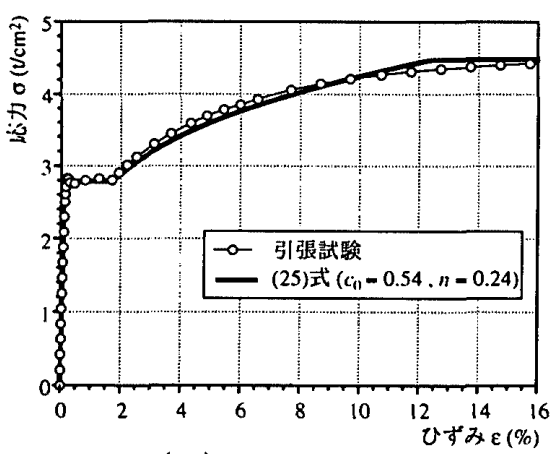

(a) PL-12 ( SS400)

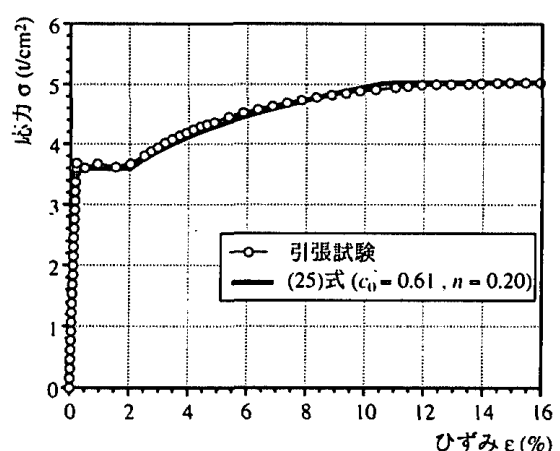

(b) PL-16 (SM490A)

图ー13 素材の応力ーひずみ関係のモデル化（引張時）

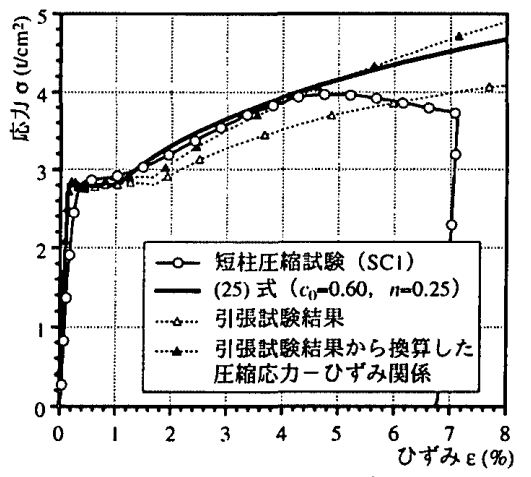

图-14 素材の応力ーひずみ関係の モテル化（圧縮時） 


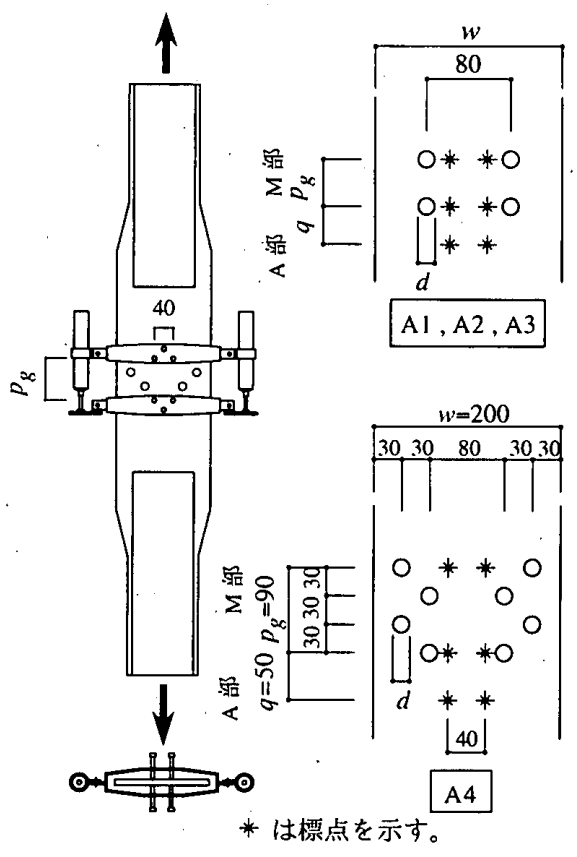

图-15 有孔板の引張試験片の 形状と測定方法

表－4 有孔板の引張試験片の一覧 (単位 : $\mathrm{mm}$ )

\begin{tabular}{|c|c|c|c|c|c|c|c|}
\hline \multirow{2}{*}{$\begin{array}{c}\text { 試験体 } \\
\text { 名称 }\end{array}$} & \multirow{2}{*}{ 材貿 } & \multirow{2}{*}{$\begin{array}{c}\text { 板幅 } \\
\text { " }\end{array}$} & \multirow{2}{*}{$\begin{array}{c}\text { 板厚 } \\
t_{f}\end{array}$} & \multirow{2}{*}{$\begin{array}{c}\text { 孔径 } \\
d\end{array}$} & \multirow{2}{*}{ 孔配置 } & \multicolumn{2}{|c|}{ 標点間距離 } \\
\hline & & & & & & $p_{k}$ & $q$ \\
\hline Al & SS 400 & 150 & 12 & 17 & 2 列 & 45 & 37.5 \\
\hline A2 & SS 400 & 150 & 12 & 21.5 & 2 列 & 55 & 37.5 \\
\hline A. 3 & SM490A & 200 & 16 & 17 & 2 列 & 45 & 37.5 \\
\hline A4 & SS 400 & 200 & 12 & 17 & 千鳥 & 90 & so \\
\hline
\end{tabular}

対数ひずみで表せば引張応力下と圧縮応力下の応力ーひ ずみ関係は一致するが，公称応力と公称ひずみで表すと 圧縮時の応力の方が大きくなる。そこで, 確認のため図 ー 17 に示すような十字断面の短柱圧縮試験を行った。そ の結果を近似する材料定数として，図ー14に示すように SS400 の場合に $c_{0}=0.60, n=0.25$ を得た。なお，参考 のため, 同じ材料の引張時の応力ーひずみ関係と, それ から真応力と対数ひずみを経由して換算した圧縮時の応 カーひずみ関係をあわせて示す。また，SM490A の場合 は短柱圧縮試験は行っていないが, 引張試験結果からの 同様の換算により， $c_{0}=0.70, n=0.20$ とする。

(2) 有孔板の引張時の応力-ひずみ関係

Fisher $^{6)}$ によれば, 有孔板の隣り合う孔の間の平均ひ ずみ $\bar{\varepsilon}$ と孔控除した断面についての有効応力 $\sigma_{e}$ との間 の関係は次式で近似できる。

$$
\left.\begin{array}{l}
\sigma_{e}=\Psi_{e t}(\bar{\varepsilon}) \\
0 \leq \bar{\varepsilon}<\bar{\varepsilon}_{y}: \Psi_{e t}(\bar{\varepsilon})=\frac{A}{A_{e}} E \bar{\varepsilon} \\
\bar{\varepsilon}_{y} \leq \bar{\varepsilon}: \Psi_{e t}(\bar{\varepsilon})=\sigma_{y}+\left(\sigma_{u}-\sigma_{y}\right) \\
\cdot\left[1-\exp \left\{-\alpha\left(\sigma_{u}-\sigma_{y}\right) \frac{A}{A_{e}}\left(\bar{\varepsilon}-\bar{\varepsilon}_{y}\right)\right\}\right]^{\frac{3}{2}}
\end{array}\right\}
$$

ここで， $\bar{\varepsilon}_{y}=A_{e} / A \cdot \sigma_{y} / E ， A$ は板の全断面積， $A_{e}$ は孔 を控除した断面積， $\sigma_{u}$ は引張強さ， $\alpha$ は実験定数であ る。また，上式の逆関係は次式となる。

$$
\left.\begin{array}{rl}
\bar{\varepsilon}=\Psi_{e l}^{-1}\left(\sigma_{e}\right) & \\
0 \leq \sigma_{e}<\sigma_{y}: \Psi_{e l}^{-1}\left(\sigma_{e}\right)= & \frac{A_{e}}{A} \frac{\sigma_{e}}{E} \\
\sigma_{y} \leq \sigma_{e}: \Psi_{e t}^{-1}\left(\sigma_{e}\right)= & \frac{A_{e}}{A} \frac{\sigma_{e}}{E}-\frac{A_{e}}{A \alpha\left(\sigma_{u}-\sigma_{y}\right)} \\
& \cdot \ln \left\{1-\left(\frac{\sigma_{e}-\sigma_{y}}{\sigma_{u}-\sigma_{y}}\right)^{\frac{2}{3}}\right\}
\end{array}\right\}
$$

Fisher は, ASTMのA7とA440の鋼材について行った有 孔板の引張試験より $\alpha=1.0 \mathrm{in}^{2} / \mathrm{kips}=14.2 \mathrm{~cm}^{2} / \mathrm{tf}$ として いるが, JIS 鋼材の場合および孔が千鳥配置の場合につい ての適用性を確認する必要がある。また，ひずみの最も 集中する梁の内端ボルト孔近傍部の応力ーひずみ関係も 知る必要がある。

そこで，図ー15 と表ー4に示す試験体について引張試 験を行った。孔と孔の間の部分（M 部）および孔の隣の 部分 (A 部) について標点間の伸びを測定し, 有効応力 と平均ひずみの関係を求めた。 $\mathrm{A}$ 部の評点距離のとり方 は，加藤ら ${ }^{10)}$ のFEM解析結果を参考にして，孔の中心か ら45 の範围に塑性域が集中すると仮定し，板幅の $1 / 4$ と した。その結果，図一16に示すように，孔が 2 列配置の 場合および千鳥配置の場合ともに， $\alpha=10.0 \mathrm{~cm}^{2} / \mathrm{tf}$ とす れば(26) 式はM 部についての実験結果をよく近似するこ とがわかった。なお, 孔が千鳥配置の場合の有効断面積 の計算は「鋼構造設計規準」い)の方法によった。また， $\mathrm{A}$ 部についてもM 部と同じ式が適用できることがわかっ た。 
（3）有孔板の圧縮時の応力-ひずみ関係

有孔板が圧縮される場合の平均ひずみと有効応力との 関係は，ひずみが小さい範囲では引張の場合と同じと考 えられる。しかし，孔がある程度変形すると孔の縁が高 カボルトの軸部に接触して，孔のない板と同じ挙動を示 すようになると考えられる。そこで，図ー17に示すよう に高力ボルトを入れた状態で十字断面の短柱圧縮試験を 行った。その結果, 図一18に示すような応力ひずみ関 係が得られたので，これを次式で近似する。

$$
\left.\begin{array}{l}
\sigma_{e}=\Psi_{c c}(\bar{\varepsilon}) \\
0 \leq \bar{\varepsilon}<\bar{\varepsilon}_{y}: \Psi_{c c}(\bar{\varepsilon})=\frac{A}{A_{c}} E \bar{\varepsilon} \\
\bar{\varepsilon}_{y} \leq \bar{\varepsilon}<\bar{\varepsilon}_{c}: \Psi_{c c}(\bar{\varepsilon})=\sigma_{y}+\left(\sigma_{u}-\sigma_{y}\right) \\
\qquad\left[1-\exp \left\{-\alpha\left(\sigma_{u}-\sigma_{y}\right) \frac{A}{A_{e}}\left(\bar{\varepsilon}-\bar{\varepsilon}_{y}\right)\right\}\right]^{\frac{3}{2}}
\end{array}\right\}
$$

ここで， $\bar{\varepsilon}_{c}$ はボルトの軸部が孔に接触するときのひずみ であり， $\bar{\varepsilon}_{s}$ は次式で与えられるひずみである。

$$
\bar{\varepsilon}_{s}=\left(\frac{A_{c} \Psi_{c t}(\bar{\varepsilon})}{A \sigma_{y} c_{0}}\right)^{\frac{1}{n}} \varepsilon_{y}
$$

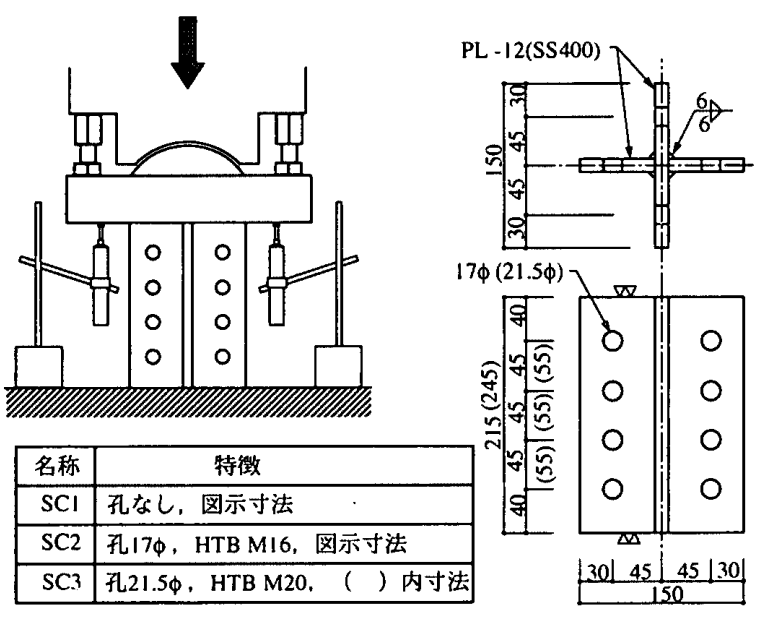

图-17 短柱圧縮試験体と载荷方法

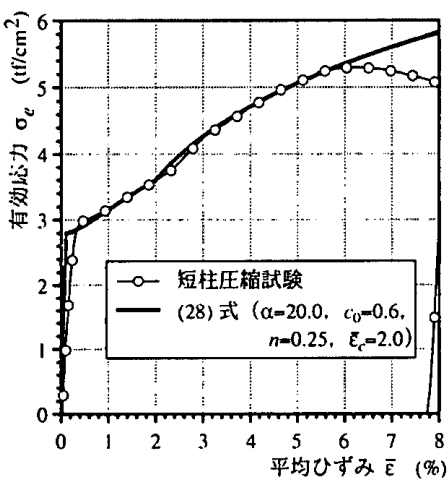

(a) $\mathrm{SC2}$

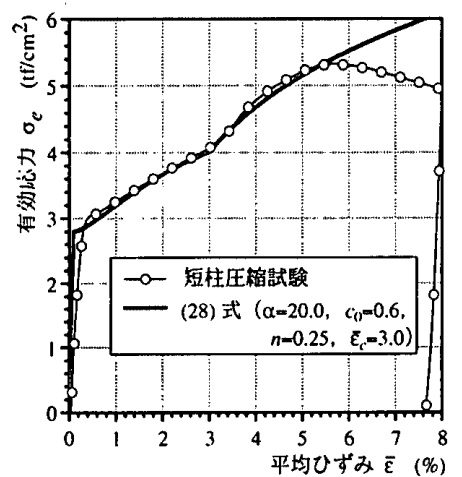

(b) $\mathrm{SC} 3$
图-18 有孔板の応力ーひずみ関係のモデル化（圧縮時）
図一 18 の実線で示すように， $c_{0}$ と $n$ を孔のない板要素の 值と同じとし， $\alpha=20.0$, ボルト孔のクリアランスが $1.0 \mathrm{~mm}$ のとき $\bar{\varepsilon}_{c}=2.0 \%, 1.5 \mathrm{~mm}$ のとき $\bar{\varepsilon}_{c}=3.0 \%$ とすると 実験結果とよく一致する。

(4) 高力ボルトのせん断力と支圧変形量の関係

Fisher $^{6)}$ によれば，高力ボルトのせん断力 $R$ と支圧変 形量 $\Delta$ の関係は次式によって近似できる。

$$
\begin{aligned}
& \Delta=\Omega(R)=\frac{-1}{\mu} \ln \left\{1-\left(\frac{R}{R_{u l t}}\right)^{\frac{1}{\lambda}}\right\} \\
& R=\Omega^{-1}(\Delta)=R_{u l t}\{1-\exp (-\mu \Delta)\}^{\lambda}
\end{aligned}
$$

ここで， $R_{u l t}$ は高力ボルトの最大せん断耐力， $\mu$ と入は ボルト径と鋼板の材質によって決まる定数である。

Fisher $^{5)}$ は種々のボルトと鋼板の組合せについて引張 せん断と圧縮せん断の実験を行い, 組合せに応じた $\mu$ と 入を求めている。しかし，それらはASTM の規格による 鋼材を使用した 2 面せん断試験によるものなので，本実
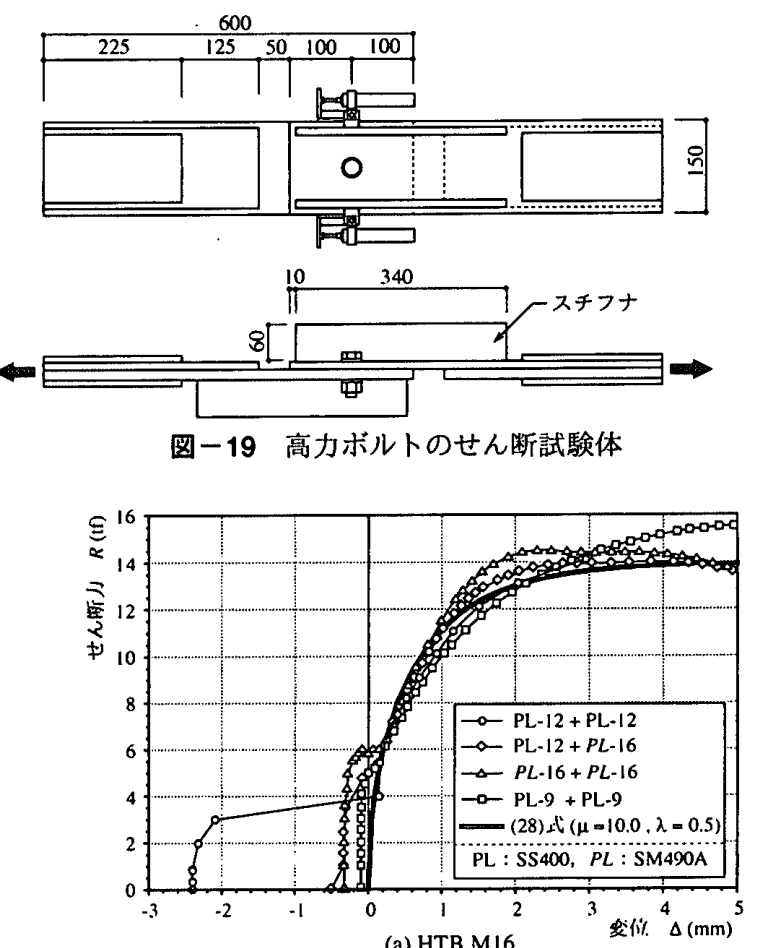

(a) HTB M 16

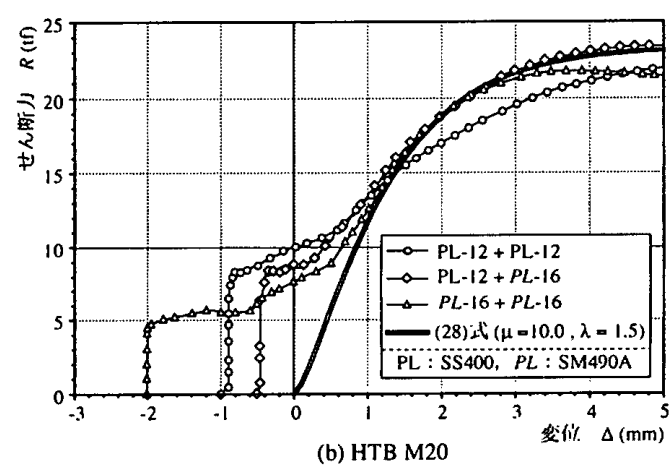

图－20 高力ボルトのせん断力 一支圧変形関係のモデル化 
験の解析には適用できない。そこで，図ー19に示すよう な 1 面せん断の試験を行った。摩擦力の影響を考虑する ため, 試験体の摩擦面はサンダーがけとし，高力ボルト は標準ボルト張力で締め付けた。実験結果を図一20に示 す。ただし，滑り変位のばらつきを排除するために，支 圧状態に入ったときの変位がほぼ一致するようにグラフ の横軸を移動している。鋼板の厚さや材質によって多少 差があるが，図中に実線で示すようにM16 のとき $\mu=10.0, \lambda=0.5, \mathrm{M} 20$ のとき $\mu=10.0, \lambda=1.5$ とすれば 実験結果を近似できる。

\section{4. 解析結果}

3 章で提示した解析方法で各試験体の変形を計算し， 実験結果との比較を行った。なお，梁母材部の分割長さ は 40mm とした。

まず，先に図ー10で梁のひずみ分布の測定結果を示し

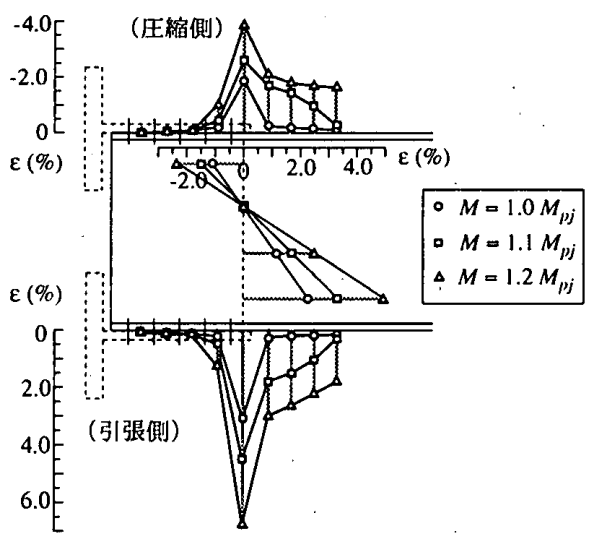

图－21 解析による梁のひずみ分布の例（S170-10）
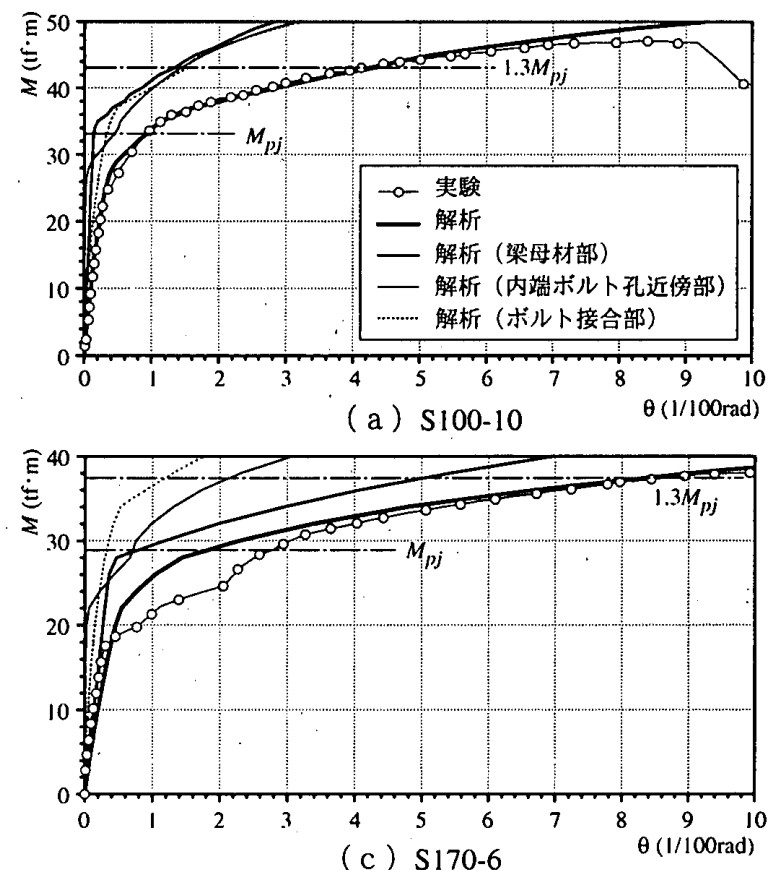

图-22 解析と実験の比較例（曲げモーメントー部材角関係）
たS170-10について本解析で得られたひずみ分布を図一 21 に示す。測定值が梁フランジ先端の局部的なひずみを 示しているのに対し，解析值は各要素の平均的なひずみ を示しているので，それらの值は必ずしも同じにはなら ないが，ひずみ分布に関しては解析結果は実験結果に対 応していると言える。

図一22に代表的な試験体についての曲げモーメントー 部材角関係を示す。中線，細線，破線はそれぞれ梁母材 部，内端ボル卜孔近傍部，ボルト接合部のみが変形する と考えたときの全体の部材角を示し，それらの和を太線 で示す。S170-6の試験体ではボルト孔のクリアランスが 大きくボルトの滑り変形が大きいため, 解析值と実験值 の差が大きい部分があるが，その他の点では本解析は実 験の曲げモーメントー部材角関係を良く捕えているとい える。

解析による各部の変形性状を詳細に見ると, 梁母材部 は当然のことながら溶接タイプの梁と良く似た曲線を描 いている。これに対して内端ボルト孔近傍部は，内端ボ ルト位置が全塑性モーメントに達する荷重 $M_{p j}$ の80\%程 度まではほとんど変形しないが，それ以後は急激に変形 が増増加している。 また，ボル卜接合部は最初から荷重 に比例して若干の変形をしているが, $M_{p j}$ の付近から増 加の度合いを強めている。ただし，実際には摩擦が切れ て滑りが生ずるまではボルトの支圧変形は生じないの で，それまでの変形はもっと小さくなると考えられる。

各部の変形量が全体に占める比率は荷重のレベルに よって異なるので，実験の最大耐力よりも $0.1 M_{p j}$ 程度 小さい荷重での変形量で比較する。これは，本解析が梁 の局部座屈を考慮していないので, 最大耐力付近では解
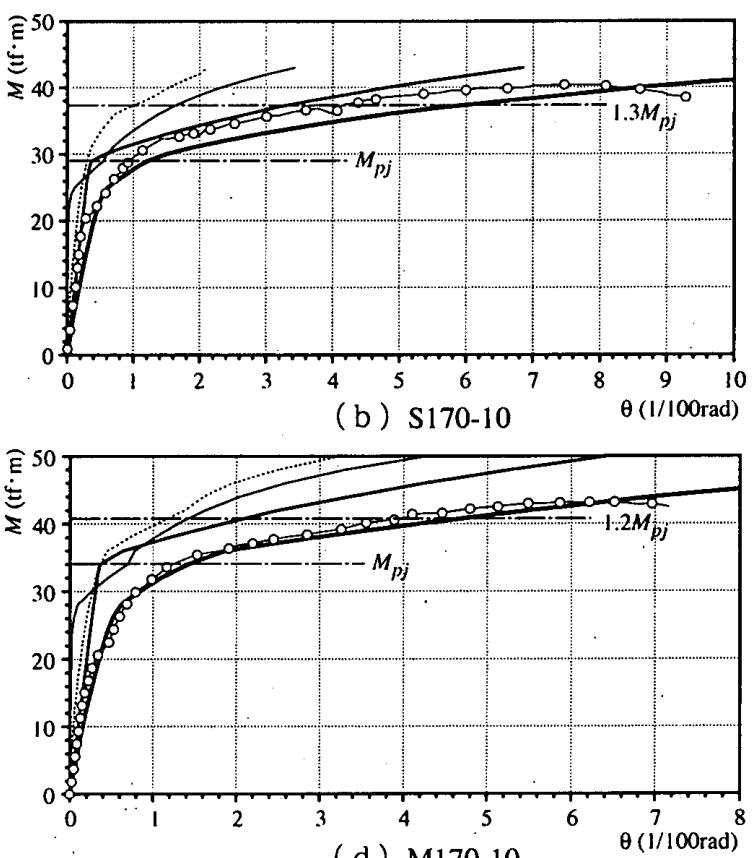

(d) $\mathrm{M} 170-10$ 
- 奏験值 /解析值（（）内数值）

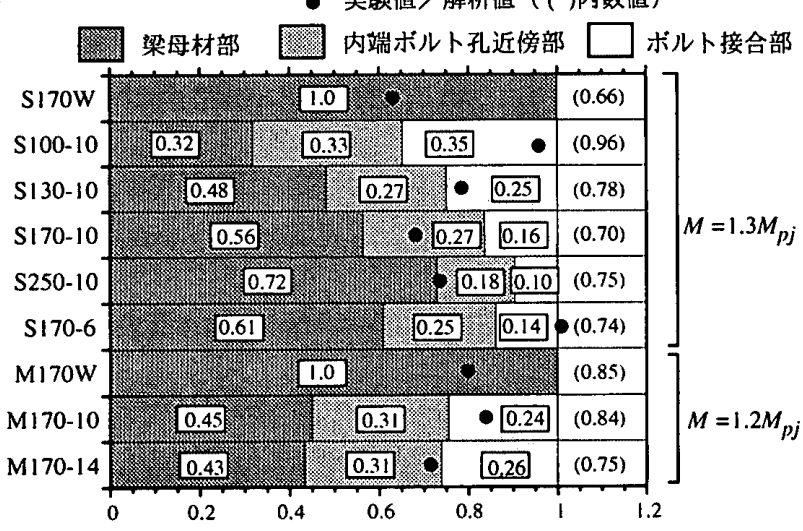

図一23解析による各部の変形比率と夷験值の比較

析と実験との間に大きな差が生じることが避けられない ためである。Sシリーズの方がフランジの幅厚比が小さ いので耐力上昇率が高くなっていることも考慮し，ここ では, $\mathrm{S}$ シリーズの試験体については $1.3 M_{p j}, \mathrm{M}$ シ リーズについては $1.2 M_{p j}$ のレベルにおける変形をと り，全ての試験体についてその比率を図一23に示す。こ れによれば，内端ボル卜孔近傍部とボルト接合部の変形 は同程度であり，スパンが短くなるほど全体の変形にそ れらの占める割合が大きくなり，50\%以上になる場合も あることがわかる。

さらに同じ荷重レベルにおける全体の変形についての 解析値に対する実験值の比を同じ図一 23 に・印で示す。 実験值はS100-10を除いて，解析值よりも2 割程度小さ くなっている。このことは溶接タイプの 2 体の試験体に ついても言えることなので，本論で示した接合部の解析 法と言うよりはむしろ梁母材部の解析法にそのような傾 向が存在すると考えられる。また，S100-10 とS170-6だ けが他と比べて実験值の比率が高くなっている理由とし ては，前者については解析においてせん断力による全塑 性モーメントの低下を無視していること, 後者について は摩擦面の滑り量が大きいことが考えられる。

\section{5. 結論}

本論文では，端部に高力ボルト重ね継手を有するH形 鋼梁の塑性変形性状を調べるために，スプリットティー 形式の接合部を持つ梁の載荷実験を行い，以下の知見を 得た。

（1）スプリットティー接合された梁の全塑性曲げ耐力 と最大曲げ耐力は, 梁の内端のボルト位置までのスプ リットティー部を剈域と仮定することで評価できる。

（2）スプリットティー接合された梁の塑性変形能力は 接合部を剛域と仮定して予测される值よりも大きくな り，その傾向はスパンが短くなるほど顕著になる。

（3）スプリットティー接合された梁に繰り返し截荷し たときの荷重 一変形関係の骨格曲線は, 単調载荷時の荷
重一変形関係とほほ一致する。

つぎに，スプリットティーと梁との接合部をボルト位 置で材軸方向に分割し，それらの要素の釣り合い条件式 と適合条件式から接合部全体の弾塑性変形を求める解析 法を提案するとともに，解析の基礎となる有孔板の引 張・圧縮変形性状と高力ボルトの支圧変形性状を実験を もとにモデル化した。

さらに，本解析法によって実験結果の検討を行い，以 下の結果を得た。

（1）本解析法によるスプリットティー接合された梁の 荷重一変形関係は実駼結果と良く対応する。

（2）全塑性モーメントの1.2 1.3 倍の荷重レベルでの 高力ボル卜接合部と梁の内端ボルト孔近傍部の变形は同 程度である。

(3) 梁のスパンが短いほど上記の変形の和が全体の変 形にしめる比率が高くなり，50\%以上になる場合もあ る。

\section{参考文献}

1) 田中淳夫，高梨晃一：保有接合された高力ボルト接合は り継手の挙動, 日本建筑学会論文報告集, 第346号, pp. 101 110，昭和59年 12 月

2）加藤勉, 田中淳夫 : 高力ボルト引張接合に関する実験的 研究（その三）柱はり接合部としての性状, 日本建築学 会論文報告集, 第151号, pp.31 38，昭和43年9月

3）舟橋功男, 小林昌一, 沖本弘 : 支圧型高力ボルトを用い た柱一接合の実験研究, 日本建築学会大会学術講演梗概 集, pp.939 940, 昭和 45 年 9 月

4) Douty, R. T., and Mcguire, W.: High Strength Bolted Moment Connections, Jour. of the Struct. Div., Proc. of the ASCE, pp. $101 \sim 128,1965-4$

5) Fisher, J. W., and Rumpf, J. L. : Analysis of Bolted Butt Joints, Jour. of the Struct. Div., Proc. of the ASCE, pp.181 203, 1965-10

6) Fisher, J. W. : Behavior of Fasteners and Plates with Holes, Jour. of the Struct. Div., Proc. of the ASCE, pp.265 286, 1965-6

7) 加藤 勉, 秋山宏 : 鋼構造部材の酎力（その 4 ）, 日本 建築学会論文報告集, 第151号, pp.15 20, 昭和 43 年9月

8) 青木博文, 加藤勉, 丁 峰: 高炉厚板鋼板の機械的性㙺 と応力ーひずみ関係の数式表示, 日本建築学会構造系諭 文報告集, 第398号, pp.73 85，1989年4月

9) 青木博文, 竺振宇: 構造用銅材の力学的特性のばらつき が梁部材の曲げモーメントと材端回転角の関係に及ほす 影響, 鋼構造年次論文報告集, 第 1 巻, pp.233 240, 1993年7月

10) 加藤勉, 青木博文 : 応力集中を有する変断面材の伸び能 力と降伏比, 日本建築学会論文報告集, 第159号, pp.25 $\sim 30$, 昭和 44 年 5 月

11) 日本建築学会 : 鋼構造設計規準, 1973年

（1995年 1 月10日原稿受理，1995年 4 月20日採用決定） 